\title{
THE GENOCIDE AND THE COMMAND RESPONSIBILITY IN CRIMINAL LAW OF THE REPUBLIC OF SERBIA
}

\author{
Dragan Jovašević \\ University of Niš, Faculty of law \\ Republic of Serbia
}

International criminal law, as a system of legal regulations found in

acts of the international community and criminal legislations of individual states, establishes criminal liability and punishments for crimes against international law. These acts represent breaches of the laws and customs of war (international humanitarian law) that violate or threaten peace among nations and the security of mankind. Penalties prescribed for these criminal offences stand for the most severe penalties in contemporary criminal legislation. In some cases, international judiciary (supranational) institutions such as The Nurnberg and The Tokyo Tribunal, The Hague Tribunal, The Rome Court etc. have primary jurisdiction over perpetrators of these criminal offences.

This criminal offence means the killing of a nation or a tribe. Genocide was proclaimed as "a crime under international law, which is in contradiction with the spirit and the aims of the OUN and condemned by the entire civilized world" by UN General Assembly Resolution 96/I from 11 December 1946. Although it emerged as a "subspecies of crime against humanity", genocide rapidly obtained an autonomous status and contents as one of the most serious crimes of today. As a crime against international law, genocide is determined by three elements: a) the objective component- actus reaus b) the subjective component- mens rea c) the subject of the act-the group-the victim. The source of this incrimination is found in Convention on the Prevention and Punishment of the Crime of Genocide from 1948, which, in paragraph 2, defines the term and the elements of this crime against international law. In legislation, theory and practice, this term can be interpreted in the broader sense, as well. In this papet the author has analysed theoretical and practical aspects of genocide in international criminal law and criminal law of Republic of Serbia (former FR Yougoslavia).

Key words: international law, humanity, crime, genocide, court, command responsibility, penalty 


\section{The genocide according in the Criminal code of the Republic of Serbia}

\section{System of international crimes}

$\mathrm{C}$ hapter 34. of the new Criminal Code of The Republic of Serbia ${ }^{1}$ contains the following "genuine" crimes against international law:
1) genocide (paragraph 373),
2) crime against humanity (paragraph 371 ),
3) war crime against civilian population (paragraph 372),
4) war crime against the wounded and sick (paragraph 373),
5 ) war crime against prisoners of war (paragraph 374) and
6) organizing and incitement to Genocide and War Crimes (paragraph 375).

\section{The notion and basic characteristics of the genocide}

The crime of genocide, from paragraph 370. of The Criminal Code of The Republic of Serbia, consists of ordering or committing the following acts: killing or causing serious bodily or mental harm to members of the group, deliberately inflicting on the group conditions of life calculated to bring about its physical destruction in whole or in part, imposing measures intended to prevent births within the group, forcibly transferring children of the group to another group, with intent to destroy, in whole or in part, a national, ethnical, racial or religious group of people. ${ }^{2}$

The word "genocide" is a compound, created from a Greek word genos, meaning nation or tribe, and a Latin word caedes, which means killing or slaughter (massacre). When translated literally this word stands for the extermination of an entire nation or tribe. ${ }^{3}$ Genocide was proclaimed as "a crime against international law, which is in contradiction with the spirit and the aims of the OUN and condemned by the entire civilized world" by OUN General Assembly Resolution 96/1 from 11 December 1946.

In spite of the fact that it initially emerged as a "subspecies of crime against humanity", genocide rapidly obtained autonomous status and contents as one of the most serious crimes of today. Nowadays, it is also called "the crime above all crimes". As a crime against international law, genocide is determined by three elements: ${ }^{4}$

1) the objective component - actus reaus,

2) the subjective component - mens rea and

3 ) the subject of the act - the victim (the group).

\footnotetext{
${ }^{1}$ Official journal of the Republic of Serbia No. : 85/2005, 88/2005, 107/2005, 72/2009, 111/2009, 121/2012, 104/2013 and 108/2014. More: D. Jovašević, Krivični zakonik Republike Srbije sa uvodnim komentarom, Beograd, Službeni list, 2007.

${ }^{2}$ D. Jovašević, Krivično pravo, Posebni deo, Beograd, Dosije, 2014. pp. 305-311.

${ }^{3} \mathrm{~S}$. Zadnik, Kaznena djela protiv vrijednosti zaštićenih međunarodnim pravom i novine u zakonodavstvu u svezi sa tim djelima, Hrvatska pravna revija, Zagreb, No.12, 2003. pp. 83-86.

${ }^{4}$ D. Radulović, Međunarodno krivično pravo, Podgorica, Kultura, 1999. p. 103.
} 
The source of this incrimination is found in Convention on the Prevention and Punishment of the Crime of Genocide ${ }^{5}$ from 1948, which defines the contents and the elements of this crime against international law.

In legislation, theory and practice this term has a more extensive interpretation. Namely, this expression includes not only killing but also extermination, committed in any other way, of a particular group that forms a consistent entity based upon national, ethnical, racial or religious foundation. The subject of protection includes humanity and international law.

The subject of attack is a national, ethnical, racial or religious group. ${ }^{6}$

A national group is comprised of people who have the feeling of sharing the legal bond of the same citizenship accompanied by reciprocal rights and obligations.

An ethnical group consists of the members who are bound by the same language and culture, whereas a racial group is a group based upon hereditary physical characteristics, which is often associated to a particular geographical area regardless of linguistic, cultural, national, or religious factors.

A religious group includes members who share the same religious convictions, the same name of the confession or the same means of conducting religious ceremonies.

In fact, the terms such as national, ethnical, racial or religious group are still being studied widely and precise definitions that would be universally and internationally accepted have not been found yet. Thus, each of these terms has to be assessed in the light of an actual political, social and cultural milieu. ${ }^{7}$

Although the act is committed by destroying individuals, it is not intended to eliminate those individuals as separate persons, but as the members of the group. Depending on the actual subject, genocide can appear as national or ethnical genocide or ethnocide if the subject is a national or an ethnical group.

In the case of racial genocide, the criminal act is directed against a particular racial group or against several groups of that kind. Religious genocide is directed against the members of one or more religious groups. The group is not to be determined in accordance with an objective or static criterion. Instead, the way the perpetrator perceives the members of the group is of fundamental importance for the definition of this term, which is also the standpoint of the ad hoc tribunals. ${ }^{8}$

The lack of definitions of genocide that would include cultural genocide comprised of destroying the language or the culture of a particular group is often stressed in legal theory.

Therefore, the aim of the act is to destroy a group, in whole or in part, whereas the elimination of an individual simply represents a means of its accomplishment. The size of the group is of no significance for the completion of the criminal offence. It is essential that the group is present as an entity carrying specific characteristics, and that it is intended to be destroyed as such. The objective of the incrimination is to guarantee the right to life, i.e. existence and development for each group carrying specific national, ethnical, racial or religious features, regardless of the spatial cohesion of its members.

\footnotetext{
${ }^{5}$ Official journal of the SFR Yougoslavia No. 56/1950.

${ }^{6}$ D. Jovašević, Komentar Krivičnog zakona SR Jugoslavije, Beograd, Službeni glasnik, 2002. pp. 11-17.

${ }^{7}$ D. Jovašević, Međunarodno krivično pravo, Niš, Pravni fakultet, 2011. pp. 89-93.

${ }^{8}$ B. Petrović, D. Jovašević, Međunarodno krivično pravo, Sarajevo, Pravni fakultet, 2010, pp. 219-221.
} 
The act consists of several acts that can be classified in a number of groups. These are the following acts: ${ }^{9}$

1) killing or causing serious bodily or mental harm to members of a specific national ethnical, racial or religious group,

2) inflicting on the group conditions of life calculated to bring about its physical destruction in whole or in part,

3) imposing measures intended to prevent births within the group (the so-called biological genocide) and

4) forcible transfer of children from one group to another intended to cause the loss of their group identity.

All these acts ${ }^{10}$ contribute to physical and biological completion of genocide. To complete this act, it is enough to commit any of the acts precisely pointed out in the law, with the intent to exterminate (destroy), in whole or in part, a group as a social entity. Genocide represents a typical example of criminal offences that rest upon the „depersonalization of the victim", which means that the victim does not represent the objective (aim) of the act due its individual qualities or features, but solemnly for being a member of a certain group.

The perpetration can be completed in two ways: ${ }^{11}$

1) by ordering and

2) by directly conducting certain acts.

Giving orders to commit the abovementioned acts represents a special and autonomous act of genocide. In fact, ordering is a form of incitement. However, in this case ordering is not characterized as complicity, but as a special way to perpetrate this criminal offence. The crime of genocide is usually committed in an organized manner and in accordance with a previously arranged plan giving particular authority to the order of a superior, which causes the autonomous nature of his responsibility. Therefore, the superior will be responsible only for having given the order to commit genocide, even if the subordinate refuses to obey or in any other way manages to avoid executing such order. ${ }^{12}$

The consequence of the act is manifested as threatening the survival of a certain national, ethnical, racial or religious group. It can be accomplished through causing a smaller or a larger number of individual consequences comprised of injuries (of life, of physical integrity, of a fetus) and threats (by inflicting on the group unbearable living conditions). ${ }^{13}$ The number of individual acts committed is of no significance for the completion of this criminal offence. This means that only one act of genocide will be committed when one, as well as when several relevant acts have been conducted. The fact that a larger number of acts causing various individual consequences were committed has an impact on the determination of sentence. This indicates that planned and systematic extermination of human groups constitutes the essence of the crime of genocide.

\footnotetext{
${ }^{9}$ S. Fabijanić Gagro, M.Škorić, Zločin genocida u praksi međunarodnih ad hoc tribunala, Zbornik Pravnog fakulteta u Zagrebu, Zagreb, No. 6, 2008. pp. 1387-1419: V. Đ. Degan, Zločin genocida pred međunarodnim krivičnim sudištima, Zbornik Pravnog fakulteta u Zagrebu, Zagreb, No.1-2, 2008.pp.77-95.

${ }^{10}$ A. Kaseze, Međunarodno krivično pravo, Beograd, Beogradski centar za ljudska prava, 2005. pp. 115-117.

${ }^{11}$ D. Jovašević, V. Ikanović, Međunarodno krivično pravo, Banja Luka, Univerzitet Apeiron, 2015, pp. 312-315.

${ }^{12}$ S. Horović, Genocid, ratni zločini i zločin protiv čovečnosti, Zbornik Pravnog fakulteta u Mostaru, Mostar, 2004. pp. 99-113.

${ }^{13}$ Lj. Lazarević, B.Vučković, V.Vučković, Komentar Krivičnog zakonika Crne Gore, Cetinje, Obod, 2004. pp. 1021-1023.

${ }^{14}$ F. Bačić, Krivično pravo, Posebni dio, Zagreb, Pravni fakultet, 1986. p. 316.
} 
Any person can be the perpetrator of this act, and, when guilt is concerned, direct premeditation (dolus coloratus), including genocidal intent, is required. Instead of applying the theory of intent, the assessment of such intent is based upon experience. The punishment prescribed for this act is minimum five years' imprisonment or thirty to forty years' imprisonment. The Criminal Code explicitly points out that this criminal act cannot be subject to limitation for criminal prosecution and enforcement of penalty.

\section{The crime against humanity}

At last, genocide and crime against humanity (that are often treated as equal by legal theory as well as by certain international legal acts such as the Statute of the International Military Tribunal in Nürnberg) have several similar features including the following: ${ }^{15}$

1) in both cases, the acts are aimed to cause massive killing of other persons,

2) both acts include severe violations that insult humanity and

3 ) neither of the acts represents an isolated case, but is usually a part of a broader conception.

However, one can perceive evident dissimilarities between them, including the following: ${ }^{16}$

1) genocide contains genocidal intent, whereas crime against humanity does not,

2) the target population of genocide is a group that has to possess shared group characteristics, while the victims of crime against humanity are determined by political preferences, physical characteristics or by the very fact that they found themselves on a certain area in a certain period of time,

3 ) crime against humanity represents a broader term since it is committed within an extensive and systematic attack the perpetrator is aware of, which is not requested as an essential and constitutive element of the crime of genocide and

4) crime against humanity can be committed by conducting a wider range of diverse acts, not all of which are covered by the term of genocide. ${ }^{17}$

\section{Responsibility of a superior (command responsibility)}

Criminal legal system of The Republic of Serbia decisively supports the standpoint according to which criminal responsibility as a personal (individual) and subjective responsibility of a perpetrator or an accomplice represents the ground for enforcement of penalties and other criminal sentences.

Apart from subjective criminal responsibility, the latest Criminal Code from 2005 is familiar with the institution of responsibility of a superior as well. Actually, responsibility of a superior as a form of "objective" responsibility is also provided by the Statute of the

\footnotetext{
15 Z. Pajić, Zločin protiv čovečnosti - problem međunarodne odgovornosti, Jugoslovenska revija za međunarodno pravo, Beograd, No. 2-3, 1986. pp. 304-316.

${ }^{16}$ B. Petrović, D. Jovašević, A. Ferhatović, Krivično pravo 2, Sarajevo, Pravni fakultet, 2016, pp. 242-244.

${ }^{17}$ D. Jovašević, Međunarodna krivična dela - odgovornost i kažnjivost, Niš, Pravni fakultet, 2010. pp. 263-268.
} 
permanent International Criminal Court and can be applied by national judiciary authorities in criminal proceedings against the persons who committed some of the criminal offences from Chapter 34. of The New Criminal Code of the Republic of Serbia entitled "Criminal Offences Against Humanity And Other Rights Guaranteed by International Law". ${ }^{18}$

In accordance with these solutions, the new Criminal Code of The Republic of Serbia from 2005 actually stipulates criminal responsibility and liability for punishment in the case of "responsibility of a superior"19 in its paragraph 384. under the title "Failure to Prevent Crimes against Humanity and other Values Protected under International Law". In fact, this provision stipulates a particular crime against international law that is comprised of failure to act. There are several forms of this criminal offence.

This legal provision also stipulates a particular form of criminal responsibility of a person who does not undertake the necessary measures to prevent the commission of the following criminal offences against humanity and other rights guaranteed by international law: ${ }^{20}$

1) genocide,

2) crime against humanity,

3) war crime against the civilian population,

4) war crime against the wounded and sick,

5 ) war crime against the prisoners of war,

6) employment of prohibited means of warfare,

7) unlawful killing and wounding of enemy,

8) unlawful appropriation of objects from bodies,

9) violation of protection granted to bearer of flag of truce/emissary,

10) cruel treatment of the wounded, sick and prisoners of war and

11) destroying cultural heritage.

These acts actually represent the preparation for the commission or the commission of the gravest criminal offence of today.

The first form of this criminal offence can be committed by a military commander or a person who in practice is discharging such function. It is therefore a criminal offence that can be committed only by a perpetrator with particular characteristics i.e. delicta propria. This criminal offence includes the following three elements ${ }^{21}$ :

1) that the perpetrator was aware or conscious of the fact that other persons were conducting preparations or directly committing the enumerated crimes against international law,

2 ) that crimes against international law were committed by the persons who entered the forces within the perpetrator's command or control and

3 ) that the perpetrator did not undertake (failed to undertake) the measures that he could have and was obliged to undertake in order to prevent the commission of the above mentioned crimes against international law, which actually resulted in their commission.

\footnotetext{
${ }^{18}$ D. Jovašević, Krivično pravo, Opšti deo, Beograd, Dosije, 2016. p. 229-232.

${ }^{19}$ B. Kozjak, Zapovjedna odgovornost u međunarodnom i hrvatskom kaznenom pravu, Odvjetnik, Zagreb, No. 5-6, 2001. pp. 37-40; B. Brkić, Zapovjedna kaznena odgovornost - mogući teoretski i praktični aspekti, Hrvatska pravna revija, Zagreb, No. 2, 2002. pp. 111-116.

${ }^{20}$ D. Jovašević, Međunarodna krivična dela - odgovornost i kažnjivost, Niš, Pravni fakultet, 2010. pp. 189-193.

${ }^{21}$ B. Ivanišević, G. Ilić, T. Višnjić, V. Janjić, Vodič kroz Haški tribunal, Beograd, 2007. pp. 133-151.
} 
The punishment prescribed for this criminal offence is the same punishment that would be imposed on the direct perpetrator of some of the enumerated crimes against international law.

Hence, the fact that some of the above mentioned criminal offences were committed by a subordinate does not absolve his superior from criminal responsibility.

The second form of this criminal act from paragraph 384 of The Criminal Code of The Republic of Serbia is related to the failures of other superiors to act, which resulted in the commission of the mentioned crimes against international law. This criminal offence requires that three following elements are met: ${ }^{22}$

1) that the perpetrator knew or was aware of the fact that other persons were preparing or directly commencing the commission of the enumerated crimes against international law,

2) that these crimes against international law were committed by perpetrator's subordinates, i.e. the persons who were subordinated to him in the execution of their tasks and

3) that the perpetrator did not undertake (failed to undertake) the measures that he could have and was obliged to undertake in order to prevent the commission of the above mentioned crimes against international law, which actually resulted in the commission of these acts.

The punishment prescribed for this criminal offence is the punishment of imprisonment that can be imposed on the direct perpetrator of one of the enumerated crimes against international law. If one of the forms of this criminal offence was committed by negligence as a form of guilt, an imprisonment of six months to five years is prescribed.

\section{The common criminal design (joint criminal enterprise) - new form of criminal responsibility}

When criminal responsibility is concerned, a special form of responsibility for crimes against international law called common criminal design, ${ }^{23}$ common purpose ${ }^{24}$ or joint criminal enterprise has lately been more and more frequently discussed in the theory and even more in the practice of international criminal law.

These standpoints (theories) are based upon the fact that the majority if crimes against international law do not represent a result of a single person's conduct or decision. In fact, crimes against international law committed in those situations represent a result, i.e. a consequence of joint enterprise of several persons who either directly perpetrated these criminal offences or inspired others to do so or planned or otherwise facilitated direct commission of these criminal offences. The use of this ground for criminal responsibility

\footnotetext{
${ }^{22}$ D. Jovašević, Krivično pravo, Posebni deo, Beograd, 2014. pp. 336-337.

${ }^{23}$ This term was first created in the English law of the $14^{\text {th }}$ century and then transplanted and further developed in the American criminal law, especially in the provisions related to organized crime. It is based upon the effort to make the proving of grave criminal offences easier, which enables the group of possible perpetrators to be expanded by including persons who otherwise could not be considered as perpetrators of such criminal offences. This is also a way of creating a new form of common or collective guilt.

${ }^{24}$ It is thought that this institution was implemented for the first time in the appeals judgment of The Hague Tribunal in the Tadic case in 1999.
} 
under international criminal law implies that all the members of the group acting with a "common purpose" are considered as responsible for a crime against international law. ${ }^{25}$

According to the practice of The Hague Tribunal (Tadić case) ${ }^{26}$ common criminal purpose exists if the following constitutive (objective) elements are fulfilled:

1) the presence of several persons ${ }^{27}$ on a specific level of cohesion. Such cohesion does not necessarily have to indicate the presence of a consistent organization with the form of a military, police, political or administrative structure, but a certain form of joint enterprise is required,

2) the presence of a common project, plan, conception or purpose that includes the commission of a crime against international law. Such plans or purposes do not necessarily have to be strictly arranged or previously formulated. They can also be "improvised" or even "accepted on the spot" by the persons acting together and

3 ) the participation of the perpetrator in such common criminal design (the contribution of the perpetrator). Such participation does not have to be confirmed by the commission of a criminal offence. The act of the perpetrator comprised simply of helping or facilitating or other contribution to the process of the commission of a common plan or purpose is considered as sufficient. ${ }^{28}$

The Statute of the International Criminal Court (The Rome Statute) also prescribes joint criminal enterprise in its paragraph 25. subpart 3. point " $d$ ". According to this provision, a person shall be criminally responsible for a crime within the jurisdiction of the Court if that person contributes to the commission or attempted commission of such a crime by a group of persons acting with a common purpose.

The institution of joint criminal enterprise significantly differs from the traditional continental system of criminal law. It is said to have the following missing: $:^{29}$

1) it allows a person to be considered as guilty although that person did not have the intent (consciousness and will) that would give reason for the constitution of guilt,

2) guilt is imposed on one person for the predictable actions of another (without clear arguments),

3) significantly different acts of persons who participate in the commission of a criminal offence are wrongfully treated as equal,

4 ) it is nit in accordance with the principle of legality and

5) the existence of this institution is especially disputable when it comes to proving, since it allows the innocent persons to be punished as well.

\footnotetext{
${ }^{25}$ D. Jovašević, Međunarodna krivična dela - odgovornost i kažnjivost, Niš, Pravni fakultet, 2010. pp. 191-194.

${ }^{26}$ The institution of joint criminal enterprise has been used several times in: 1) the practice of The Hague Tribunal: judgment 00-39-T (The Krajišnik case), judgment 98-32 (The Vasiljević case), judgment: 95-14 (The Blaškić case) and judgment 98-33 (The Krstić case), 2) the practice of The Rwanda Tribunal: judgment 96-17 (The Nakirutimana case) and 3) the practice of Special Panels for Serious Crimes in East Timor through the judgments in the following cases: Pereira, Domingos de Deus and Cardoso

${ }^{27}$ A participation of a smaller number of persons in the commission of particular crimes on a limited territory is considered as enough to form "the presence of several persons" in the sense of joint criminal enterprise. These persons need to know (be familiar with) each other because they act together and there is a consent among them on the commission of criminal offences.

${ }^{28}$ B. Ivanišević, G. Ilić, T. Višnjić, V. Janjić, Vodič kroz Haški tribunal, Beograd, 2007. pp. 119-121.

${ }^{29}$ M. Damaška, Boljke zajedničkog zločinačkog poduhvata, Hrvatski ljetopis za kazneno pravo i praksu, Zagreb, No. 1, 2005. 3-11.
} 
Such contribution shall be considered as intentional and shall either: ${ }^{30}$

1 ) be made with the aim of furthering the criminal activity or criminal purpose of the group, where such activity or purpose involves the commission of a crime within the jurisdiction of the Court or

2) be made in the knowledge of the intention of the group to commit the crime.

Joint criminal enterprise can emerge in three forms. Those are:

1 ) the responsibility of all the members of the group acting with a common purpose and with a common intent to commit a particular crime against international law. In such case, not all the members of the group have to conduct direct perpetration of such criminal offence. But, if one of them voluntarily participated in an aspect of the common plan with the intent to commit such crime against international law as a result of joint enterprise, all of them will be considered as responsible and

2) the responsibility for "concentration camps", where all the persons on high positions within the camps in which these criminal offences were committed are also considered as perpetrators in spite of the fact that they did not participate in the direct perpetration.

According to the practice of The Hague Tribunal, a common plan is considered to exist in the following cases: ${ }^{31}$

a) long term and routine imprisonment and captivation of another nation's members,

b) repeated torture and beating of the imprisoned persons,

c) murder if the imprisoned persons,

d) frequent and long lasting forced labor of the imprisoned persons and

e) maintenance of inhumane conditions in the prison building.

The use of this form of responsibility requires that the following conditions are met:

1) an organized system of maltreatment of the imprisoned persons that includes the commission of some of the crimes against international law,

2) perpetrator's awareness of the nature of this system of maltreatment and

3) the fact that the perpetrator encouraged, helped, supported or otherwise participated in the conduction of the common criminal purpose due to the fact that he had the permission and the possibility to supervise the imprisoned persons and to make their life supportable and acceptable (satisfactory), but failed to do so and

4) the responsibility for the crime against international law that stands beyond the frames of the joint criminal purpose but still represents its natural and predictable consequence. This is the so called "extended" joint criminal enterprise.

\section{Conclusion}

International criminal law, as a system of legal regulations found in acts of the international community and criminal legislations of individual states, establishes criminal liability and punishments for crimes against international law. These acts represent breaches of the laws and customs of war (international humanitarian law) that violate or threaten peace among nations and the security of mankind. Penalties prescribed for

\footnotetext{
${ }^{30} \mathrm{~K}$. Ambros, Joint criminal enterprise and command responsibility, Journal of International Criminal Justice, No. 5, 2007. pp. 159-183.

${ }^{31}$ D. Jovašević, V. Ikanović, Krivično pravo, Opšti deo, Banja Luka, Univerzitet Apeiron, 2012, pp. 193-194.
} 
these criminal offences stand for the most severe penalties in contemporary criminal legislation. Due to its significance, nature and character, the crime above all crimes stands out among all the crimes against international law. It is the crime of genocide.

The act of genocide consists of ordering or committing: killing, causing serious bodily or mental harm to members of a human group or deliberately inflicting on the group conditions of life calculated to bring about its extinction in whole or in part or imposing measures intended to prevent births within the group or forcibly transferring children to another group, with the intent to destroy, in whole or in part, a national, ethnical, racial or religious group of people.

This criminal offence means the killing of a nation or a tribe. Genocide was proclaimed as "a crime under international law, which is in contradiction with the spirit and the aims of the OUN and condemned by the entire civilized world" by UN General Assembly Resolution 96/l from 11 December 1946. Although it emerged as a "subspecies of crime against humanity", genocide rapidly obtained an autonomous status and contents as one of the most serious crimes of today.

As a crime against international law, genocide is determined by three elements: a) the objective component - actus reaus $b$ ) the subjective component - mens rea c) the subject of the act-the group-the victim. The source of this incrimination is found in Convention on the Prevention and Punishment of the Crime of Genocide from 1948, which, in paragraph 2, defines the term and the elements of this crime against international law. In legislation, theory and practice, this term can be interpreted in the broader sense, as well. Namely, this term does not include only killing but also destruction, committed in any other way, of a particular group that forms a consistent entity on national, ethnical, racial or religious grounds.

Established within the frames of international law of war and international humanitarian law, international criminal law obtained its "citizenship" at the beginning of the third millennium as the newest criminal legal discipline. When The Rome Statute of the International Criminal Court came into force, this branch of law was finally inaugurated in substantial, procedural and executive sense. Even earlier than that, this branch of law had been evolving through the development of basic criminal legal terms and institutions within a series of international legal documents (of universal and regional character) or contracts between individual states as well as through the practice of the courts (first of all, the practice of the Nürnberg and Tokyo Tribunals).

The latter include the following:

1) crime against international law (which differs from a criminal offence with an international element) that can emerge in two forms: as a crime against international law in the narrow sense (genuine) or as a crime against international law in the broader sense (counterfeit or mixed),

2) criminal responsibility of the perpetrator (the precondition for criminal responsibility is the fact that the perpetrator is more than 18 years old), who can appear either as one person or include several persons or even a legal person such as a state or an organization and

3 ) the system of criminal sentences i.e. punishments that are being imposed by the supranational judiciary authorities.

These fundamental terms and institutions of international criminal law are discussed in this paper.

Because of the nature, the character and the hazard of crimes against international law, this branch of law is familiar with a special form of objectified responsibility besides individual criminal responsibility. It is the responsibility of political and military superiors 
for the crimes against international law committed by their subordinates, known as the responsibility of a superior, which is entering national criminal legislations through relevant international standards. Accordingly, the latest Criminal Code of The Republic of Serbia from 2005. also includes this institution.

\section{Literature}

[1] Official journal of the Republic of Serbia No.: 85/2005, 88/2005, 107/2005, 72/2009, $111 / 2009,121 / 2012,104 / 2013$ and 108/2014.

[2] Official journal of the SFR Yougoslavia, No. 56/1950.

[3] D. Jovašević, Krivični zakonik Republike Srbije sa uvodnim komentarom, Beograd, Službeni list, 2007.

[4] D. Jovašević, Krivično pravo, Posebni deo, Beograd, Dosije, 2014.

[5] S. Zadnik, Kaznena djela protiv vrijednosti zaštićenih međunarodnim pravom i novine u zakonodavstvu u svezi sa tim djelima, Hrvatska pravna revija, Zagreb, No.12, 2003

[6] D. Radulović, Međunarodno krivično pravo, Podgorica, Kultura, 1999.

[7] D. Jovašević, Komentar Krivičnog zakona SR Jugoslavije, Beograd, Službeni glasnik, 2002.

[8] D. Jovašević, Međunarodno krivično pravo, Niš, Pravni fakultet, 2011.

[9] B. Petrović, D. Jovašević, Međunarodno krivično pravo, Sarajevo, Pravni fakultet, 2010.

[10] S. Fabijanić Gagro, M.Škorić, Zločin genocida u praksi međunarodnih ad hoc tribunala, Zbornik Pravnog fakulteta u Zagrebu, Zagreb, No. 6, 2008.

[11] V. Đ. Degan, Zločin genocida pred međunarodnim krivičnim sudištima, Zbornik Pravnog fakulteta u Zagrebu, Zagreb, No.1-2, 2008.

[12] A. Kaseze, Međunarodno krivično pravo, Beograd, Beogradski centar za ljudska prava, 2005.

[13] D. Jovašević, V. Ikanović, Međunarodno krivično pravo, Banja Luka, Univerzitet Apeiron, 2015.

[14] S. Horović, Genocid, ratni zločini i zločin protiv čovečnosti, Zbornik Pravnog fakulteta u Mostaru, Mostar, 2004.

[15] Lj. Lazarević, B.Vučković, V.Vučković, Komentar Krivičnog zakonika Crne Gore, Cetinje, Obod, 2004.

[16] F. Bačić, Krivično pravo, Posebni dio, Zagreb, Pravni fakultet, 1986.

[17] Z. Pajić, Zločin protiv čovečnosti - problem međunarodne odgovornosti, Jugoslovenska revija za međunarodno pravo, Beograd, No. 2-3, 1986.

[18] B. Petrović, D. Jovašević, A. Ferhatović, Krivično pravo 2, Sarajevo, Pravni fakultet, 2016.

[19] D. Jovašević, Međunarodna krivična dela - odgovornost i kažnjivost, Niš, Pravni fakultet, 2010.

[20] D. Jovašević, Krivično pravo, Opšti deo, Beograd, Dosije, 2016.

[21] B. Kozjak, Zapovjedna odgovornost u međunarodnom i hrvatskom kaznenom pravu, Odvjetnik, Zagreb, No. 5-6, 2001.

[22] B. Brkić, Zapovjedna kaznena odgovornost - mogući teoretski i praktični aspekti, Hrvatska pravna revija, Zagreb, No. 2, 2002.

[23] B. Ivanišević, G. llić, T. Višnjić, V. Janjić, Vodič kroz Haški tribunal, Beograd, 2007.

[24] M. Damaška, Boljke zajedničkog zločinačkog poduhvata, Hrvatski ljetopis za kazneno pravo i praksu, Zagreb, No. 1, 2005.

[25] K. Ambros, Joint criminal enterprise and command responsibility, Journal of International Criminal Justice, No. 5, 2007. 